\title{
Sustainable Rural Development: Strategies, Good Practices and Opportunities
}

\author{
Ana Nieto Masot* (D) and José Luis Gurría Gascón (D) \\ Department of Art and Territorial Sciences, University of Extremadura, 10071 Cáceres, Spain; jlgurria@unex.es \\ * Correspondence: ananieto@unex.es
}

Citation: Masot, A.N.; Gascón, J.L.G. Sustainable Rural Development: Strategies, Good Practices and Opportunities. Land 2021, 10,366. https://doi.org/10.3390/land10040366

Received: 22 March 2021

Accepted: 23 March 2021

Published: 2 April 2021

Publisher's Note: MDPI stays neutral with regard to jurisdictional claims in published maps and institutional affiliations.

Copyright: (c) 2021 by the authors. Licensee MDPI, Basel, Switzerland. This article is an open access article distributed under the terms and conditions of the Creative Commons Attribution (CC BY) license (https:// creativecommons.org/licenses/by/ $4.0 /)$.
In 2020, a special issue titled "Sustainable Rural Development: Strategies, Good Practices and Opportunities" was launched, in which 16 papers were published. The aim of this monograph is to study a problem that is occurring on a global scale and, above all, in the most developed countries, which is the population emigrate from rural areas to urban areas due to the labour and service opportunities offered by the latter [1,2]. This is causing a demographic deterioration of rural areas due to the abandonment in large areas of numerous villages, and those that remain show high rates of ageing, masculinisation or low demographic growth [3-5]. In addition, and interrelated with this demographic deterioration, there was economic [6] and environmental degradation [7-9]. Rural areas are territories with increasingly lower purchasing power, job opportunities and services for the population [10] which are classified as "spaces in crisis" [11-13]. In addition, and due to the abandonment of agricultural holdings [14,15], it is causing problems such as the increase in desertification, deforestation and even risk phenomena such as forest fires [16-19].

The aim of this special issue was to present, on the one hand, contributions in which different initiatives or projects are managed to reduce the demographic, economic and social imbalances between rural and urban areas. On the other hand, it aimed to present some studies that highlight the weaknesses that certain projects are having in achieving the same objectives. The papers presented are very varied and provide cases in a wide variety of territories, in European, American or Asian regions where there are rural areas in crisis and, a review [20] on the opportunities that may arise for rural areas to introduce integration of technology such as Internet networks, telecommuting, distance-learning education, the use of electric cars, etc. to achieve development.

There are strategies focused on achieving rural development through the promotion of activities complementary to agriculture. Agriculture was the predominant activity in rural areas until decades ago [21] and has become a minority activity due to the transformations of the global economy and its greater mechanisation [22] and it does not generate enough income to sustain the population in rural areas. For this reason, the agricultural sector should be complemented with other economic activities in rural areas, as recommended by organisations such as the EU [21-23] and the OECD [2,24-26]. Thus, there are papers in which different types of complementary activities, such as rural tourism, the revaluation of natural heritage, the promotion of agroecological products, the transformation of agricultural areas into industrial land, the introduction of ICTs and internet access in rural areas, improve their communications and teleworking or the design of sustainable housing that can fundamentally attract new settlers. In addition, some papers that have focused on initiatives with new models of development, such as Leader at European level or the design of smart villages, have been put forward. As a complement, other papers have focused on the design of indicator models to measure the sustainable rural development strategies.

In the following paragraphs, the main results of the papers presented are detailed.

In Spain, there are cases presented such as the strategies carried out in the rural and coastal communities of Galicia [27], where the aim has been to achieve complementary incomes for fishermen by means of the diversification of the Common Fisheries Policy aid 
(CFP). It focused on creating synergies between the fishing sector and tourism and trying to implement a fishing tourism. However, its results are not yet as expected in terms of employment despite the financial support, not only from EU aid, but also from the regional government. This is due to the fishermen's lack of experience and previous training in tourism activities, their advanced age, the irregular distribution of these activities and the regulatory restrictions of the Spanish legal system that made it very difficult for people other than the crew to embark on boats dedicated to fishing as their main activity.

There is a study about Murcia [28], which analyses the transformation of large areas in this region into irrigated land over the last 30 years (the majority of which are former rainfed areas). The conclusions presented in this work show that although at an economic level they are obtaining high profitability and favouring the stabilisation of the population in this region, at an environmental level and due to the water deficit in this region, the consequences are not as beneficial. They present an excessive dependence on water transfers from hydrographic basins in other regions such as those of the Tagus river, an over-exploitation of aquifers and the reduction of natural flows and, lastly, the possibility of the disappearance of these areas in future decades if these external transfers diminish.

LEADER programme aid and their entrepreneurs are analysed in Andalusia [29]. The authors focus on two aspects: social and spatial disparities in the distribution of funds and the success or failure of the projects granted in the period 2007-2015. In the results on failed projects, those that were granted but not executed, it is determined that this was due to different causes: the degree of rurality, women and young people and the distance to cities had higher failure rates, and therefore those placed with a higher success rate were the projects located in peri-urban areas.

Being Extremadura the study area, four papers are presented. The first one focuses on the analysis of the LEADER programme [30] in a mountain territory, based on the intangible aspect of the design and success of these development programmes (less studied because most approaches have focused on economic aspects). Using a qualitative methodology with surveys of relevant actors who have participated in the process (public and government sectors, businessmen, associations), it has been determined that aspects such as the contribution of LEADER to the county identity are well valued, but others, such as the participation of the local population in decision-making, are still considered to be scarce.

The second one [31] shows the success that a polycentric system of small towns well distributed throughout the territory can help to maintain the rural population in certain areas located in Extremadura through rural-urban partnerships and integrated territorial investments. A polycentric system can help in the design of new political strategies in the fight against the demographic challenge and in the recovery of the so-called "empty Spain".

The third paper [32] focuses on how hunting tourism in rural areas with a deeprooted hunting tradition is favouring the introduction of new incomes by creating an accommodation infrastructure. The results of this paper (carried out with questionnaires and statistical techniques) show that hunting tourists also take advantage of their stay to carry out other activities in the area, which can produce synergies with other sectors such as restaurants and leisure activities complementary to hunting.

Finally, the fourth analyses [33] the business agglomerations in rural districts (LAG) of LEADER. A typology of three classes according to their number of companies, employment, specialization, income generated, weight within the region and their degree of innovation is created. The results show those areas where there are booming industrial sectors related to a specialisation sector, mostly agri-food or meat, and which can be exploited by the rural development strategies of the rural districts in their investments.

A new composite indicator of sustainable rural development was established for Aragón [34]. It is based on the vulnerability of the ecosystem services being designed. This indicator is tested in 10 study areas and results in a ranking that produces a greater disparity in levels of development when vulnerability is added to the process, suggesting 
that the environmental dimension and the perspective from which it is conceived and applied are important in approaching sustainable rural development.

The activities that have enhanced the value of territorial heritage in declining areas are analysed in Castilla la Mancha [35]. It highlighted through the creation of a co-operation strategy between two counties that have a mining park and a Geopark, both recognised by UNESCO as World Heritage Sites. This strategy of harnessing the potential synergy between the two resources and offering a shared quality tourism resource has also been developed in collaboration between the institutions (top-down approach) and supported by the local population (bottom-up) as co-operative strategies that aim to minimise depopulation processes in areas in crisis.

Outside Spain but within in Europe, a paper about Poland [36] is presented. It is one of the initiatives being promoted by the EU, the design of smart villages, where establishing new technologies and an efficient internet network could favour the maintenance of the population in rural areas. In this work and using detailed socio-economic data, an association has been established between poor internet access and rural decline. The pre-liminary findings of implementing smart villages in Poland present theoretical and methodological dilemmas, but these are expected to be overcome as the implementation of these initiatives helps to encourage other areas to participate because of improvements in their economic incomes and maintenance of the population.

About America, there are two papers. The first is about Mexico [37], and more specifically in rural areas of the Yucatan Peninsula, where the aim has been to achieve sustainable rural development by supporting agroecological products. In this study, interviews were carried out to analyse the role of entrepreneurs and their vision of public policies in the promotion of this activity in order to achieve development. The visions obtained were pessimistic because there is still a policy of little support for these activities, inadequate management and trust in the public management and in the structure of the sector itself. In addition, the entrepreneurs say they encounter other problems as the still low profitability due to an insufficient commercial distribution network, the lack of ecological awareness among consumers and the lack of training of the farmers themselves when it comes to carrying out their projects.

The second in the USA [38] is a case study on new sustainable residential construction in rural areas with a pilot project in Texas. They analysed the most efficient materials and energy systems with the lowest economic cost. It is to show a model that in the medium term recovers the additional investment in the construction of this sustainable housing and that positively affects the environment by reducing pollution and the use of non-renewable energies. As a proposal, the authors argue that administrations should promote regulations and codes that advocate the implementation of this type of construction in rural areas that can encourage new settlers to move in.

Finally, three papers are in Asia, two of them in China and another in Kazakhstan.

The first one in China has focused [39] on the leasing of forestland by farmers for sustainable harvesting and income extension and the factors that contribute to its success. The results show that the age and educational level of the farmers, the proportion of income from other non-agricultural sources, the benefits they obtain from these leases and whether institutional and market factors facilitate the procedures (simpler in some areas than in others) have encouraged them to expand their income with other activities carried out on the leased forest land.

The second one in China [40] has focused on designing a weighted geographical regression model to analyse a pilot land reform system in 25 cities in the Dingzhou area, consisting of the transfer of industrial land to agricultural land. Positive correlations will be obtained with the price of industrial transfer land in those areas with demographic and economic growth, greater population density, health resources and proximity to cities because they are the most demanded and most profitable. It can be a reference model for the sustainable use of industrial land. 
The paper of Kazakhstan [41] is about the agricultural intensification of peri-urban areas in the Shortandy district based on an integrated study of land use dynamics and sustainable development indicators (SDI). The results show that the increase of agricultural land in peri-urban areas is achieving economic, social and environmental development. Therefore, the methodological approach can be a starting point for similar studies in other areas and also these new uses can produce economic and social development in declining rural areas which, due to their proximity to the city, can take advantage of this proximity to produce flows between them.

The papers in this special issue evidence the many public and private strategies that are being pursued to achieve sustainable rural development in declining areas. The diversity of approaches and challenges offer a vision of the practical application of these strategies and the obstacles or difficulties that many of them are having to achieve their objectives. All of these strategies intended to achieve economic dynamism that is respectful of the environment and from there to be able to reduce the regressive demographic processes in rural areas. These are different approaches that allow us to contribute, from scientific, holistic and multidisciplinary knowledge, new strategies that can help decision making in public policy managers and in equitable planning and management strategies. It is a current issue that can still be further developed in new special monographs due to the numerous initiatives and projects that are being carried out.

Funding: This research has had the support and funding of the European Regional Development Fund (ERDF), European Social Fund (ESF) and Government of Extremadura (Spain) funded this research and the APC to the DESOSTE research group (Grant number GR18052).

Conflicts of Interest: The authors declare no conflict of interest.

\section{References}

1. MacDonald, D.; Crabtree, J.R.; Wiesinger, G.; Dax, T.; Stamou, N.; Fleury, P.; Gutierrez Lazpita, J.; Gibon, A. Agricultural abandonment in mountain areas of Europe: Environmental consequences and policy response. J. Environ. Manag. 2000, 59, 47-69. [CrossRef]

2. OECD. Competitive Cities in a Global Economy; OECD: Paris, France, 2006.

3. Lutz, W.; Sanderson, W.; Scherbov, S. The coming acceleration of global population ageing. Nature 2008, 451, 716-719. [CrossRef] [PubMed]

4. Schoeni, R.F.; Ofstedal, M.B. Key themes in research on the demography of aging. Demography 2010, 47, S5-S15. [CrossRef]

5. Johnson, K.M.; Lichter, D.T. Rural Depopulation: Growth and Decline Processes over the Past Century. Rural Sociol. 2019, 84, 3-27. [CrossRef]

6. De Cos Guerra, O.; Reques Velasco, P. Vulnerabilidad territorial y demográfica en España. Posibilidades del análisis multicriterio y la lógica difusa para la definición de patrones espaciale. J. Reg. Res. 2019, 45, 201-255.

7. Molinero Hernando, F. El espacio rural de España: Evolución, delimitación y clasificación. Cuad. Geográficos 2019, 58. [CrossRef]

8. Coleman, D.; Rowthorn, R. Who's Afraid of Population Decline? A Critical Examination of Its Consequences. Popul. Dev. Rev. 2011, 37, 217-248. [CrossRef]

9. Smailes, P.J.; Argent, N.; Griffin, T.L.C. Rural Population Density: Its Impact on Social and Demographic Aspects of Rural Communities. J. Rural Stud. 2002, 18, 385-404. [CrossRef]

10. Delgado Viñas, C. Depopulation Processes in European Rural Areas: A Case Study of Cantabria (Spain). Eur. Ctry. 2019, 11, 341-369. [CrossRef]

11. Carpio Martín, J. Desarrollo local en los espacios rurales. Polis 2000, 2. Available online: https://journals.openedition.org/polis/ 7803 (accessed on 9 October 2020).

12. Ocaña, M.C. El espacio rural andaluz, permanencias y cambios de la crisis abierta a mediados de siglo. Cuad. Geográficos 2000, 30, 77-95.

13. Nieto Masot, A.; Cárdenas Alonso, G.; Engelmo Moriche, Á. Design of a Development Index for Spanish Municipalities. Sustainability 2020, 12, 8910. [CrossRef]

14. Mantero, G.; Morresi, D.; Marzano, R.; Motta, R.; Mladenoff, D.J.; Garbarino, M. The influence of land abandonment on forest disturbance regimes: A global review. Landsc. Ecol. 2020, 35, 2723-2744. [CrossRef]

15. Varga, D.; Vila Subirós, J.; Barriocanal, C.; Pujantell, J. Landscape Transformation under Global Environmental Change in Mediterranean Mountains: Agrarian Lands as a Guarantee for Maintaining Their Multifunctionality. Forests 2018, 9, 27. [CrossRef]

16. Rey Benayas, J.M.; Martins, A.; Nicolau, J.M.; Schulz, J.J. Abandonment of agricultural land: An overview of drivers and consequences. Cab Rev. 2007, 2, 14. [CrossRef] 
17. Lasanta, T.; Arnáez, J.; Pascual, N.; Ruiz-Flaño, P.; Errea, M.P.; Lana-Renault, N. Space-time process and drivers of land abandonment in Europe. Catena 2017, 149, 810-823. [CrossRef]

18. Pausas, J.G.; Fernández-Muñoz, S. Fire regime changes in the Western Mediterranean Basin: From fuel-limited to drought-driven fire regime. Clim. Chang. 2012, 110, 215-226. [CrossRef]

19. Viedma, O.; Moity, N.; Moreno, J. Changes in landscape fire-hazard during the second half of the 20th century: Agriculture abandonment and the changing role of driving factors. Agric. Ecosyst. Environ. 2015, 207, 126-140. [CrossRef]

20. Gomes, E. Sustainable Population Growth in Low-Density Areas in a New Technological Era: Prospective Thinking on How to Support Planning Policies Using Complex Spatial Models. Land 2020, 9, 221. [CrossRef]

21. Conferencia de Cork “Un Medio Rural Vivo". Available online: http:/ / www.redr.es/es/portal.do?TR=A\&IDR=1\&identificador= 770 (accessed on 20 October 2020).

22. Comisión Europea. Estrategia Territorial Europea: Hacia un Desarrollo Equilibrado y Sostenible del Territorio de la Unión Europea; Oficina de Publicaciones Oficiales de las Comunidades Europeas: Luxemburgo, 2009.

23. Comisión Europea. Dictamen del Comité Económico y Social Europeo sobre la «Propuesta de Reglamento del Consejo por el que Se Establecen Disposiciones Generales Sobre el Fondo Europeo de Desarrollo Regional, el Fondo Social Europeo y el Fondo de Cohesión; (COM(2004) 492 Final-2004/0163 (AVC); Diario Oficial de la Unión Europea: Bruselas, Belgium, 2005.

24. OECD. Iniciatives Locales de Création D'emplois: Entreprises et Emplois dans le Monde Rural; OECD: Paris, France, 1992.

25. OECD. Multifunctionality. Towards an Analytical Framework; OECD: Paris, France, 2001.

26. OECD. Strategies to Improve Rural Service Delivery. In OECD Rural Policy Reviews; OECD: Paris, France, 2010.

27. González, R.C.L.; Piñeiro Antelo, M.d.l.Á. Fishing Tourism as an Opportunity for Sustainable Rural Development-The Case of Galicia, Spain. Land 2020, 9, 437. [CrossRef]

28. García-Marín, R.; Espejo-Marín, C.; Giménez-García, R.; Ruiz-Álvarez, V. Transformations in the Agricultural and Scenic Landscapes in the Northwest of the Region of Murcia (Spain): Moving towards Long Awaited (Un)Sustainability. Land 2020, 9 , 314. [CrossRef]

29. Cejudo García, E.; Cañete Pérez, J.A.; Navarro Valverde, F.; Ruiz Moya, N. Entrepreneurs and Territorial Diversity: Success and Failure in Andalusia 2007-2015. Land 2020, 9, 262. [CrossRef]

30. Castellano-Álvarez, F.J.; Nieto Masot, A.; Castro-Serrano, J. Intangibles of Rural Development. The Case Study of La Vera (Extremadura, Spain). Land 2020, 9, 203. [CrossRef]

31. Gurría Gascón, J.L.; Nieto Masot, A. Rururban Partnerships: Urban Accessibility and Its Influence on the Stabilization of the Population in Rural Territories (Extremadura, Spain). Land 2020, 9, 254. [CrossRef]

32. Martín-Delgado, L.-M.; Rengifo-Gallego, J.-I.; Sánchez-Martín, J.-M. Hunting Tourism as a Possible Development Tool in Protected Areas of Extremadura, Spain. Land 2020, 9, 86. [CrossRef]

33. Rangel-Preciado, J.F.; Parejo-Moruno, F.M.; Cruz-Hidalgo, E.; Castellano-Álvarez, F.J. Rural Districts and Business Agglomerations in Low-Density Business Environments. The Case of Extremadura (Spain). Land 2021, 10, 280. [CrossRef]

34. Fernández Martínez, P.; de Castro-Pardo, M.; Barroso, V.M.; Azevedo, J.C. Assessing Sustainable Rural Development Based on Ecosystem Services Vulnerability. Land 2020, 9, 222. [CrossRef]

35. Ruiz Pulpón, Á.R.; Cañizares Ruiz, M.D.C. Enhancing the Territorial Heritage of Declining Rural Areas in Spain: Towards Integrating Top-Down and Bottom-Up Approaches. Land 2020, 9, 216. [CrossRef]

36. Komorowski, Ł.; Stanny, M. Smart Villages: Where Can They Happen? Land 2020, 9, 151. [CrossRef]

37. Blanco-Gregory, R.; López-Canto, L.E.; Sanagustín-Fons, M.V.; Martínez-Quintana, V. Agroecological Entrepreneurship, Public Support, and Sustainable Development: The Case of Rural Yucatan (Mexico). Land 2020, 9, 401. [CrossRef]

38. Fulton, L.; Beauvais, B.; Brooks, M.; Kruse, S.; Lee, K. Sustainable Residential Building Considerations for Rural Areas: A Case Study. Land 2020, 9, 152. [CrossRef]

39. Li, X.; Cirella, G.T.; Wen, Y.; Xie, Y. Farmers' Intentions to Lease Forestland: Evidence from Rural China. Land 2020, 9, 78. [CrossRef]

40. Yang, Z.; Li, C.; Fang, Y. Driving Factors of the Industrial Land Transfer Price Based on a Geographically Weighted Regression Model: Evidence from a Rural Land System Reform Pilot in China. Land 2020, 9, 7. [CrossRef]

41. Alipbeki, O.; Alipbekova, C.; Sterenharz, A.; Toleubekova, Z.; Makenova, S.; Aliyev, M.; Mineyev, N. Analysis of Land-Use Change in Shortandy District in Terms of Sustainable Development. Land 2020, 9, 147. [CrossRef] 